\title{
Study on Microbiological Quality of Vender Chicken Livers in Jalalabad City
}

\author{
Sayed Mohammad Weqar¹, Damier I. Udaliev², Ahmad Farid Rawan', Ahmad Aziz Kankar ${ }^{1}$ \\ ${ }^{1}$ Veterinary Science Faculty of Nangarhar University, Jalalabad, Afghanistan \\ ${ }^{2}$ Moscow State University of Food Production
}

Correspondence concerning this article should be addressed to Udaliev Damier I., Moscow State University of Food Production, , e-mail: udalievDI@mgupp.ru

\begin{abstract}
Liver is chemically complex matrixes contain sufficient nutrients that support microbial growth. Microbial contamination of vending chicken livers could occur due to different possible reasons such as storing foods in cheap utensils, holding foods at a temperature that would permit bacterial growth, utilization of water of questionable hygienic quality, using packing materials that were not of food-grade quality, vending site that has no facilities for waste disposal and utilization of unclean utensils. In addition, street chicken livers vendors are unaware of the basic importance of personal cleanliness, thus their products are usually vulnerable to gross contamination by flies, insects, rodents, dust and other dirt. Vending chicken livers are often poor and uneducated and lack appreciation for safe food handling. Aim of the study is to determine microbiological quality of chicken livers in Jalalabad city. A total of 24 samples of vender chicken livers from 4 different shops had purchased from Jalalabad city Afghanistan. This step occurred earlier than the chilling period then Transfer Directly to the Microbiological laboratory of Veterinary Science faculty of Nangarhar University for Microbial culture and microscopic examination. According to our study we have seen 6 (25\%) samples positive for Salmonella and 24(100\%) samples positive for Shigella. Studies made in Nangarhar pointed out that the important aspect of vending chicken livers is their safety and understanding the possible ways of contamination. The sanitary condition need to be improved. The government must develop microbiological standards of fast food and urgently put them in practice.
\end{abstract}

Key words: contamination, Salmonella, Shigella, food borne illness, hygiene

\section{Introduction}

The liver is the most important organ involved in metabolic processes and is considered to be one of the most eloquent witnesses of any disturbance in the body (Doneley, 2004). Liver is chemically complex matrixes contain sufficient nutrients that support microbial growth. Water availability, $\mathrm{pH}$, and temperature in meat may encourage, prevent, or limit the growth of microorganisms (Easa, 2010). The liver is a vital organ which had a high percentage of unsaturated fatty acids, proteins, vitamins and minerals could be used for human consumption as food; this organ is eaten partially or wholly cooked (Adams and Moss, 1999; Wiesenfeld et al., 2005). Edible by-products constitute about $20-30 \%$ of live weight of the animal (Umaraw et al., 2015). Edible offal such as lungs, liver, kidneys and heart, contain various nutritional components as high in vitamin content, high quality protein and energy to human beings. For example, livers are high in vitamin A, iron, zinc, vitamin $\mathrm{B}$, vitamin $\mathrm{C}$, vitamin $\mathrm{D}$, copper and fatty acids. Hearts contain large amounts of iron, selenium, zinc, phosphorous, niacin and riboflavin, but they are very low in sodium. So offal particularly, liver is consumed in large number of dishes or as common ingredients in many foods in many countries (Little et al., 2008). Meat and edible offal have long been considered as highly desirable, nutritious and proteinrich food, but at the same time unfortunately, they are also highly perishable because they provide the nutrients needed to support the growth of many types of microorganisms. Due to their unique biological and chemical nature, their quality attributes deteriorate from the time of slaughter until consumption (Kalalou et al., 2004). Liver is highly spoilage dietary material contains many non-pathogenic or pathogenic pollution if it stored in bad circumstance (Molla and Mesfin, 2003; Molla et al., 2003). There is combination between the incidence of food-borne outbreaks and consumption of the poultry meat (Lunden et al., 2003; Prakash et al., 2005). Food-borne diseases are primary public health problem conduct to increase morbidity and mortality worldwide (Thanigaivel and Anandhan, 2015). Liver could be contaminated during the slaughter of animals 
with many microorganisms like shigella, staphylococcus and E.coli (Thanigaivel and Anandhan, 2015). The wide occurring outbreaks of Staphylococcal and Bacillus cereus food poisoning may be due to inclusive handled and insalubrious cooked meat products (Zakki et al., 2017). In most of the countries, poultry and poultry products are better foods to be correlated with the diseases (Zakki et al., 2017).

Contamination of food is one of the most serious issues that the food industries of Afghanistan are facing today, which not only causes major economic losses for the processing industry, but also a major health risk for the consumers. Chicken liver is a good media for microbial growth due to high nutrient value. The microbiological quality of food during retail marking mainly depends upon the post production handling of the product, in addition to the efficiency and sanitary condition during preparing, handling, processing and storage. Contamination of food by pathogenic micro-organisms at some processing steps resulted in several disease outbreaks in numerous countries of Asia, Europe and America.

The eastern zone of Afghanistan has a long border with Pakistan. Due to the long border, liver of the various poultry imported here in various legal and illegal ways is oft low quality. Imports low quality livers and vending chicken livers are the causing Agents of food borne illness. According to these, our people have health problems and lose their money, which is the major factor of bad economic situation. For this purpose, we have to examine the quality of those vending chicken livers, which are purchased here in Jalalabad city. Vending chicken livers are not safe from insects, dirt, sewages, handling and pollutions, because storage and sales facilities do not meet hygienic standards. The aim of the study is to determine microbiological quality of chicken livers in Nangarhar.

\section{Material and Methods}

Participants of this work are Mai Aslam plaza, Angoor bagh, Talashi chaok and Pukhtunistan vender liver shopkeepers.

\section{Study area and sample collection}

A total of 24 samples of vender chicken livers from 4 different shops have been purchased from my work place Jalalabad city. Shops were mainly on the same street, one lower mid-level, one higher mid-level and one higher level. The samples were taken and kept in sterile plastic bags until the analysis.

\section{Media}

Different types of media (MacConkey agar and SS agar) were used in this study.

\section{MacConkey agar}

MacConkey agar is used as a selective and differential culture medium for bacteria. It is designed to selectively isolate Gram-negative and enteric (normally found in the intestinal tract) bacilli and differentiate their base on lactose fermentation. It contains crystal violet and bile salts, those inhibit the growth of gram-positive organisms and allowed for the selection and isolation of gram-negative bacteria.

\section{SS agar}

SS agar is selective Media for Salmonella and Shigella.

\section{Sample collection}

Samples were collected from four places of Jalalabad city and immediately put into sterile tip bag to avoid any type of outer contamination. If it had not been done immediately, samples should have been kept in the refrigerator until laboratory examination.

\section{Sampling}

The samples were serially diluting up to six times in saline solution and each of the test tubes was labeled properly. All the agar plates were also labelled properly and only the dilution from 10-3-10-6 are spread in all of the media, which were MacConkey agar and SS Agar for salmonella and Shigella. Then we presented these carriers and a sample of dilution on the plates for the microbial culture. After plating, all the plates were kept in incubator for 24-48 hours for growth.

\section{Result}

Many Vender chicken livers are perishable by nature and require protection from spoilage during their preparation, storage and distribution in order to provide them with the desired shelf life. According to our study we have seen Salmonella in 6 (25\%) samples and shigella in $24(100 \%)$ samples.

\section{Discussion}

Microorganisms cause nutritional and sensory deterioration of meat products, leading to loss of 
Table 1

Shows the Salmonella and Shigella detection percentages

\begin{tabular}{|c|c|c|c|}
\hline \multicolumn{4}{|c|}{ Result of chicken gizzards samples of Angoorbagh for the diagnosis of Salmonella and shegilla } \\
\hline Samples & salmonella + & shigella + & Negative \\
\hline 6 samples & 1 & 6 & 5 for salmonella \\
\hline Percentages \% & $16,6 \%$ & $100 \%$ & $83.4 \%$ \\
\hline \multicolumn{4}{|c|}{ Result of chicken gizzards samples of paktoonistan wat for the diagnosis of Salmonella and shegilla } \\
\hline Samples & salmonella & shegilla & Negative \\
\hline 6 samples & 1 & 6 & 5 for salmonella \\
\hline Percentages \% & $16,6 \%$ & $100 \%$ & 0 \\
\hline \multicolumn{4}{|c|}{ Result of chicken gizzards sample of khewa hada for the diagnosis of Salmonella and shegilla } \\
\hline Samples & salmonella & shegilla & Negative \\
\hline 6 samples & 3 & 6 & 3 for salmonella \\
\hline Percentage & $50 \%$ & $100 \%$ & 0 \\
\hline \multicolumn{4}{|c|}{ Result of chicken gizzards sample of mia aslam plaza for the diagnosis of Salmonella and shegilla } \\
\hline Samples & Salmonella & Shegilla & Negative \\
\hline 6 samples & 1 & 6 & 5 for salmonella \\
\hline Percentages & $16,6 \%$ & $100 \%$ & 0 \\
\hline \multicolumn{4}{|c|}{ Total result for gizzard contamination } \\
\hline Samples & Salmonella & Shegilla & Negative \\
\hline \multirow[t]{2}{*}{24 samples } & 6 & 24 & 18for salmonella \\
\hline & $25 \%$ & $100 \%$ & 75\%for salmonella \\
\hline
\end{tabular}
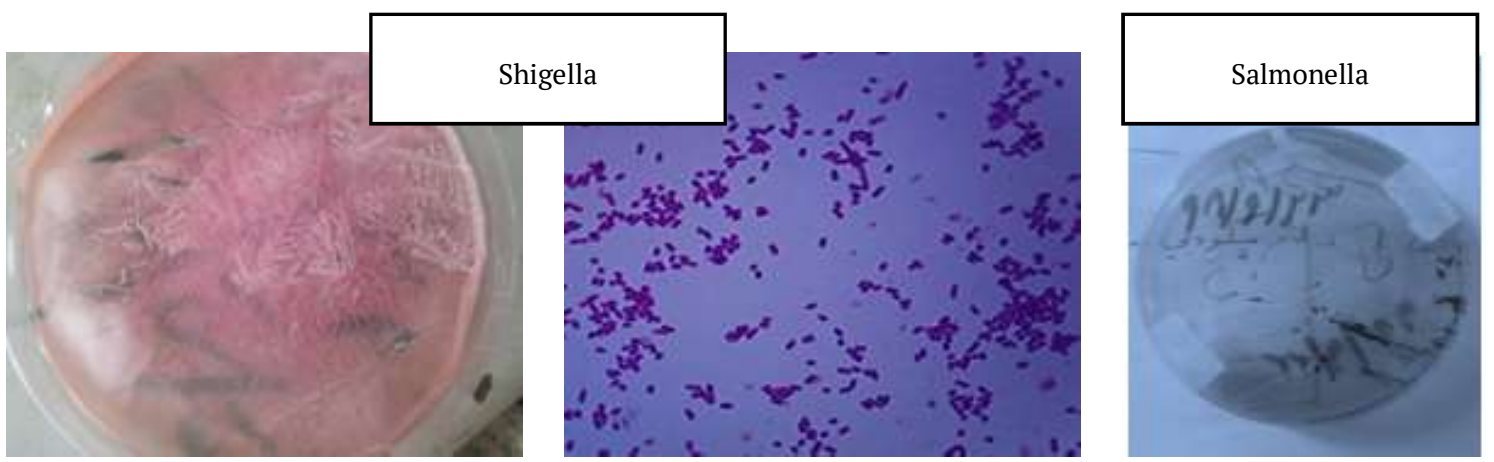

quality and shelf life limiting. Microorganisms can also be responsible for human illness. Food-borne pathogens are the leading cause of illness and death in developing countries costing billions of dollars in medical care and medical and social costs (Fratamico et al., 2005). Poultry and poultry products are frequently contaminated with Salmonellae and Shigella that can be transmitted to humans through the handling of raw poultry carcasses and products, or through consumption of undercooked poultry meat (Bailey and Cosby, 2003; Kimura et al, 2004). A study done by Bonyadian et al. in 2006 (Bonyadian et al., 2006), the percentage of Salmonellae-positive chickens was $34.45 \%$ and percentage of the Shigella positive was $55 \%$ at the end of the slaughtering process, but the present result of Salmonella is lower and the Shigella is higher than the previous ones. A study in poultry slaughterhouse of Shiraz showed that contamination of external and internal surfaces and liver of carcasses with Salmonellae were $0.4 \%$ respectively. Also, this study showed that $8.4 \%$ of carcasses were contaminated on one or more sites with Shigella (Nazer et al, 1998) but the present study result is much higher from them. However, some studies on chicken carcasses from retail shops have been shown that $19 \%$ of chickens were contaminated 
with Salmonellae in Ahvaz (Saidii asl, 1994) but the present study result is less high than the one from the Saidii's study. Nonetheless, a lower (8.5\%) incidence of the Shigella organism was reported in Shahrekord (Kuhian, 1999) but the present study result is much higher than the one from the Kuhian's study. Contamination of raw chicken has also been reported from the other countries. It depends on the regional variations. For example, the salmonella rate contamination was $60 \%$ and shigilla was $33 \%$ in Portugal (Antunes et al., 2003), 13.8\% of salmonella and $23 \%$ of shigella in Switzerland (Baumgartner et al., 1992) and $23.7 \%$ of salmonella and $12,5 \%$ of shigilla in Poland (Mikolajczyk and Radkowski, 2002). But according to our study we have seen salmonella in $25 \%$ and shigella in $100 \%$ samples.

\section{Conclusion}

We are resulting that salmonella and shigella infect chicken livers in vender. Finally, people should become more aware of having livers from outside. People selling and preparing the chicken meat and livers should also become more alert. Food safety rules and implementation of food regulatory laws in food preparation, serving and preservation should be strongly maintained to avoid contamination problems and food-borne diseases.

\section{References}

Adams, M. R., Moss, M. O. (1999). Food microbiology. Thomas Graham house.

Antunes, P., Reu, C., Sousa, J. C., Peixe, L. \& Pestana, N. (2003). Incidence of Salmonellae from poultry and their susceptibility to antimicrobial agents. International Journal of Food Microbiology, 82, 97-103.

Baumgartner, A., Heimann, P., \& Schmid, H. (1992). Salmonellae contamination of poultry carcasses and human salmonellosis. Archiv für Lebensmittelhygiene,43,123-124.

Bonyadian, M., Ale Agha, S., \& Motahari fard, A. (2006). Isolation and identification of Salmonellae from chicken carcasses in processing plants in Yazd province, central Iran. Journal of Veterinary Research, 8(3), 20.

Doneley, B. (2004). Treating liver disease in the avian patient. Saminars in Avian and Exotic Pet Medicine, $13,8-15$.

Easa, S. M. H. (2010). The microbial quality of fast food and traditional fast food. Nature and Science, $8(10), 117-133$.
Fratamico, P.M., Bhunia, A.K., \& Smith, J.L. (2005). Foodborne pathogens in microbiology and molecular biology. Caister Academic Press.

Kalalou, I., Faid, M., \& Ahami, A. T. (2004). Extending the shelf life of fresh minced camel meat at ambient temperature by Lactobacillus delbruekii subsp. delbruekii. Electronic Journal of Biotechnology, 7, 246-251.

Kuhian, K. (1999). Salmonellae on chicken carcasses in Shahrekord slaughterhouse [Doctoral Thesis, Islamic Azad University of Shahrekord]. Shahrekord, Iran.

Little, C. L., Richardson, J. F., Owen, R. J., de Pinna, E., \& Threlfall, E. J. (2008). Campylobacter and Salmonella in raw red meats in the United Kingdom: prevalence, characterization and antimicrobial resistance pattern, 2003-2005. International Journal of Food Microbiology, 25(3), 538-543.

Lunden, J. M., Autio, T.J., Sjoberg, A.M., \& Korkeala, H. J. (2003). Persistent and nonpersistent Listeria monocytogenes contamination in meat and poultry processing plants. Journal of Food Protection, 66, 2062-2069. https://doi. org/10.4315/0362- 028X-66.11.2062

Molla, B., \& Mesfin, A. (2003). A survey of Salmonella contamination in chicken carcass and giblets in Central Ethiopia. Revue de Médecine Vétérinaire, 154(4), 267-270.

Mikolajczyk, A. \& Radkowski, M. (2002). Salmonellae on chicken carcasses in processing plants in Poland. Journal of Food Protection, 65, 1475-1479.

Nazer, A. H. K., Firuzy, R. \& Ebrahimi Motlagh, K. (1998). Isolation and identification of Salmonellae serotypes from broilers slaughter in Shiraz slaughterhouses. Pajouhesh-vaSazandegi, 39, 98-100.

Prakash, B., Krishnappa, G., Muniyappa, L., \& Kumar B. S. (2005). Epidemiological characterization of avian Salmonella enterica serovar infections in India. International Journal of Poultry Science, 4(6), 388-395. https://doi.org/10.3923/ijps.2005.388.395

Saidii asl, M. R. (1994). Prevalence of Salmonellae on chicken carcasses in Ahvaz slaughterhouse. [Doctoral Thesis, University of Ahvaz]. Ahvaz, Iran.

Thanigaivel, G., \& Anandhan, A. S. (2015). Isolation and charactrization of microorganisms from raw meat obtained from different market places in and around chennai. Journal of Pharmaceutical, Chemical and Biological Sciences, 3(2), 295-301.

Umaraw, P., Pathak, V., Rajkumar, V., Verma, A. K., Singh, V. P., \& Verma, A. K. (2015). Microbial quality, instrumental texture and colour profile evaluation of edible byproducts obtained from Barbari goats. Veterinary World, 8(1), 97-102. https://doi.org/10.14202/vetworld.2015.97-102 
Wiesenfeld, P. L., Babu, U. S., Raybournr, R. B., Gaines, D, Donnell, M. O., \& Myers, M. J. (2005). Effect of dietary fish-meal on chicken serum, liver and spleen fatty acid metabolism. International Journal of Poultry Science, 4(10), 728-733.https://doi.org/10.3923/ijps.2005.728.733
Zakki, S. A., Qureshi, R., Hussain, A., Ghias, W., Sharif, M., \& Ansari, F. (2017). Microbial quality evaluation and prevalence of bacteria and fungus in different varieties of chicken meat in Lahore. Journal of Pharmaceutical Sciences, 5(1), 30-37. 


\title{
Исследование микробиологического качества куриной печени, продаваемой в Джалал-Абаде
}

\author{
Викар Саид Мохаммад ${ }^{1}$, Удавлиев Дамир Исмаилович ${ }^{2}$, \\ Раван Ахмад Фарид ${ }^{1}$, Канкар Ахмад Азиз ${ }^{1}$

\section{${ }^{1}$ Veterinary Science Faculty of Nangarhar University, Jalalabad, Afghanistan \\ ${ }^{2}$ Московский государственный университет пищевых производств}

Корреспонденция, касающаяся этой статьи, должна быть адресована Удавлиеву Дамиру Исмаиловичу, Московский государственный университет пищевых производств, е-таil: UdalievDI@mgupp.ru

\begin{abstract}
Печень представляет собой химически сложные матрицы, содержащие достаточно питательных веществ, поддерживающих рост микробов. Микробное заражение куриной печени в торговых автоматах могло произойти из-за различных возможных причин, таких как хранение продуктов в дешевой посуде, хранение продуктов при температуре, допускающей рост бактерий, использование воды сомнительного гигиенического качества, использование упаковочных материалов, не предназначенных для пищевых продуктов. качественный торговый центр, на котором нет оборудования для вывоза мусора и использования нечистой посуды. Кроме того, уличные торговцы куриной печенью не осознают первостепенной важности личной гигиены, поэтому их продукция обычно уязвима для серьезного заражения мухами, насекомыми, грызунами, пылью и другой грязью. Цель исследования - определить микробиологическое качество куриной печени в Нангархаре. Всего в Джалал-Абаде было закуплено 24 образца куриной печени от продавца из 4 различных магазино. Этот этап произошел до периода охлаждения, а затем был передан непосредственно в микробиологическую лабораторию ветеринарного факультета Университета Нангархара для микроскопических исследований. Также указано, что куриная печень, продаваемая по продаже, часто бывает бедной и необразованной, а также не ценят безопасное обращение с пищевыми продуктами.Согласно нашему исследованию, мы видели сальмонеллу в 6 (25\%) положительных пробах и шигеллу в 24 (100\%) положительных пробах. Исследования, проведенные в Нангархаре, показали, что важным аспектом при продаже куриной печени является ее безопасность и понимание возможных путей заражения. Санитарное состояние требует улучшения. Государство должно разработать микробиологические стандарты фастфуда и срочно внедрить их на практике.
\end{abstract}

Ключевые слова: заражение, сальмонелла, шигелла, пищевые заболевания, гигиена

\section{Список литературы}

Adams, M. R., Moss, M. O. (1999). Food microbiology. Thomas Graham house.

Antunes, P., Reu, C., Sousa, J. C., Peixe, L. \& Pestana, N. (2003). Incidence of Salmonellae from poultry and their susceptibility to antimicrobial agents. International Journal of Food Microbiology, 82, 97-103.

Baumgartner, A., Heimann, P., \& Schmid, H. (1992). Salmonellae contamination of poultry carcasses and human salmonellosis. Archiv für Lebensmittelhygiene,43,123-124.

Bonyadian, M., Ale Agha, S., \& Motahari fard, A. (2006). Isolation and identification of Salmonellae from chicken carcasses in processing plants in
Yazd province, central Iran. Journal of Veterinary Research, 8(3), 20.

Doneley, B. (2004). Treating liver disease in the avian patient. Saminars in Avian and Exotic Pet Medicine, 13, 8-15.

Easa, S. M. H. (2010). The microbial quality of fast food and traditional fast food. Nature and Science, 8(10), 117-133.

Fratamico, P.M., Bhunia, A.K., \& Smith, J.L. (2005). Foodborne pathogens in microbiology and molecular biology. Caister Academic Press.

Kalalou, I., Faid, M., \& Ahami, A. T. (2004). Extending the shelf life of fresh minced camel meat at ambient temperature by Lactobacillus delbruekii subsp. delbruekii. Electronic Journal of Biotechnology, 7, 246-251. 
Kuhian, K. (1999). Salmonellae on chicken carcasses in Shahrekord slaughterhouse [Doctoral Thesis, Islamic Azad University of Shahrekord]. Shahrekord, Iran.

Little, C. L., Richardson, J. F., Owen, R. J., de Pinna,E., \& Threlfall, E. J. (2008). Campylobacter and Salmonella in raw red meats in the United Kingdom: prevalence, characterization and antimicrobial resistance pattern, 2003-2005. International Journal of Food Microbiology, 25(3), 538-543.

Lunden, J. M., Autio, T.J., Sjoberg, A.M., \& Korkeala, H. J. (2003). Persistent and non-persistent Listeria monocytogenes contamination in meat and poultry processing plants. Journal of Food Protection, 66, 20622069. https://doi.org/10.4315/0362- 028X-66.11.2062

Molla, B., \& Mesfin, A. (2003). A survey of Salmonella contamination in chicken carcass and giblets in Central Ethiopia. Revue de Médecine Vétérinaire, 154(4), 267-270.

Mikolajczyk, A. \& Radkowski, M. (2002). Salmonellae on chicken carcasses in processing plants in Poland. Journal of Food Protection, 65, 1475-1479.

Nazer, A. H. K., Firuzy, R. \& Ebrahimi Motlagh, K. (1998). Isolation and identification of Salmonellae serotypes from broilers slaughter in Shiraz slaughterhouses. Pajouhesh-vaSazandegi, 39, 98-100. Prakash, B., Krishnappa, G., Muniyappa, L., \& Kumar B.S. (2005). Epidemiological characterization of avian Salmonella enterica serovar infections in India. International Journal of Poultry Science, 4(6), 388-395. https://doi.org/10.3923/ijps.2005.388.395

Saidii asl, M. R. (1994). Prevalence of Salmonellae on chicken carcasses in Ahvaz slaughterhouse. [Doctoral Thesis, University of Ahvaz]. Ahvaz, Iran.

Thanigaivel, G., \& Anandhan, A. S. (2015). Isolation and charactrization of microorganisms from raw meat obtained from different market places in and around chennai. Journal of Pharmaceutical, Chemical and Biological Sciences, 3(2), 295-301.

Umaraw, P., Pathak, V., Rajkumar, V., Verma, A. K., Singh, V. P., \& Verma, A. K. (2015). Microbial quality, instrumental texture and colour profile evaluation of edible byproducts obtained from Barbari goats. Veterinary World, 8(1), 97-102. https://doi.org/10.14202/vetworld.2015.97-102

Wiesenfeld, P. L., Babu, U. S., Raybournr, R. B., Gaines, D. ,Donnell, M. O., \& Myers, M. J. (2005). Effect of dietary fish-meal on chicken serum, liver and spleen fatty acid metabolism. International Journal of Poultry Science, 4(10), 728-733. https:// doi.org/10.3923/ ijps.2005.728.733

Zakki, S. A., Qureshi, R., Hussain, A., Ghias, W., Sharif, M., \& Ansari, F. (2017). Microbial quality evaluation and prevalence of bacteria and fungus in different varieties of chicken meat in Lahore. Journal of Pharmaceutical Sciences, 5(1), 30-37. 